\title{
CONSERVATION AND NUTRITIONAL QUALITY OF BLUEBERRY TREATED WITH EATABLE COVERING
}

\author{
Conservação e qualidade nutricional de mirtilo tratado \\ com revestimento comestível
}

Marcibela Stülpp ${ }^{1}$ Bruna Barbara Bucalão Gnas², Edmar Clemente ${ }^{3}$

\begin{abstract}
Lengthening the post-harvest life of fruits from temperate climates is one of the greatest challenges of modern agriculture, which aims at diminishing the losses and increasing the offer period of the product in national and international market. The use of eatable pellicles has been explored to cover fruits, since its usage represents an economical advantage, due to its low price and reduction of post-harvest losses. Thus, the aim of this work was to evaluate the quality of blueberry, cultivar Florida M, produced in an organic production system and covered with eatable covering based on kefir grains associated with different storage temperatures. Thus, it was observed that the most efficient treatment to reduce blueberry post-harvest loss was the combination of kefir grains in association with storage cooled at $5{ }^{\circ} \mathrm{C}$, not changing the chemical composition and nutritional of blueberry.
\end{abstract}

Index terms: Post-harvest, blueberry, kefir.

\begin{abstract}
RESUMO
Prolongar a vida pós-colheita de frutos de clima temperado é um dos grandes desafios da agricultura moderna, que tem como objetivo diminuir as perdas e aumentar o tempo de oferta do produto no mercado nacional e internacional. A utilização de películas comestíveis tem sido bastante explorada para revestimento de frutos, pois a sua utilização apresenta vantagem econômica, pelo baixo custo e redução nas perdas pós-colheita. Dessa forma, neste trabalho, objetivou-se avaliar a qualidade de mirtilo produzido no sistema orgânico de produção, cultivar Florida M, revestido com o revestimento comestível, à base de grãos de kefir, associados a diferentes temperaturas de armazenamento. Assim, observou-se que o tratamento mais eficaz na redução de perdas pós-colheita de mirtilo foi a combinação do tratamento à base de grãos de kefir associado ao armazenamento refrigerado a $5{ }^{\circ} \mathrm{C}$, não alterando a composição química e nutricional do mirtilo.
\end{abstract}

Termos para indexação: Pós-colheita, mirtilo, kefir.

\section{INTRODUCTION}

Blueberry (Vaccinium askey Read) is a fruit that belongs to family Ericaceae, subfamily Vaccinnoideae and genus Vaccinium (Donadio; Nachtigal; Sacramento, 1998). It is native to North America, being found from Southern United States to Eastern Canada. The importance of this plant is in its fruit, which it a very much appreciated sweet-savored berry (Jara-Ayala, 1999). The fruits may be used for fresh consumption, juices, jams, yogurts and others. However, there is not much offer, making most of the Brazilian population unaware of this fruit, even the population from the South of Brazil, which is the most recommended area for blueberry cultivation (Donadio; Nachtigal; Sacramento, 1998).

Blueberry tree produces fruits with diameter between $8 \mathrm{~mm}$ and $22 \mathrm{~mm}$. The berries are sweet-sour savored with several nutraceutical properties and high antioxidant potential, due to the presence of phenolic compounds (Childers; Lyrene, 2006).

In the world, there are three main groups of commercially cultivated blueberry: "low-bush" type, "high-bush" type and "rabbit-eye" type (Childers; Lyrene, 2006; Strik, 2007). Blueberry commercial cultivation is widely expanding in South American countries, such as Chile, Argentina and Uruguay, with a production area of approximately 6,500 ha. The cultivation expansion in these countries is mostly influenced by the demand of intercrops from countries from the North Hemisphere, such as the United States (Strik, 2005; Brazelton; Strik, 2007).

Such market demand may generate business opportunities for the Brazilian production sector, once technology is adopted for the production and usage of adequate cultivars (Antunes; Madail, 2005). In Brazil, the main cultivars belong to "rabbit-eye" type (Antunes; Ranseira, 2006). They have the following characteristics: high vigor, long-life plants, high productivity, tolerance

${ }^{1}$ Universidade Estadual de Maringa/UEM - Departamento de Agronomia/DAG - Maringá - PR - Brasil

2Universidade Estadual de Maringa/UEM - Departamento de Engenharia de Alimentos - Maringá - PR - Brasil

3Universidade Estadual de Maringa/UEM - Departamento de Química - 87020-900 - Maringá - PR - Brasil - eclemente@uem.br

Received in november 26, 2013 and approved in july 25, 2014 
to heat and drought, little demand in cold seasons, early blooming, long period between blooming and maturation, firm fruits with long post-harvest life (if properly, conserved) (Ehlenfeldt et al., 2007).

Another important factor for the increase in blueberry cultivation areas is the crescent interest in natural antioxidants from plant extracts, due to its low toxicity in comparison to synthetic antioxidants (Wolfe; Wu; Liu, 2003; Manach et al., 2004).

Phenolic compounds are generated in plant secondary metabolism and they are used as defenders against plague. In animals and humans, it is observed that they are able to react with free radicals, creating stable radicals. This power of neutralization of phenolic compounds radical structures is due to its chemical structure consisted of at least an aromatic ring with hydroxyl groups (Giada; Mancini-Filho, 2006). Anthocyanins are antioxidants (Wang, Cao; Prior, 1997) and dietary antioxidants are believed to play a role in reducing the risks of various human degenerative diseases (Prior et al., 1998). Carotenoids are bioactive substances in foods with powerful antioxidant bioactivity. There are abundant data showing theirs preventive effects in humans for a number of diseases (Stahl; Sies, 2003).

Besides its direct antioxidant activity, recent studies have shown multiple functions and important mechanisms related to the ability that phenolic compounds have to link to cell receptors and membrane transporters and to influence genic expression, signalization and cellular adhesion (Manach, 2004).

The use of eatable covering has been widely explored to cover fresh fruits and vegetables, aiming at diminishing humidity loss and reducing respiration rate, besides bestowing a bright and attractive appearance (Azeredo, 2003). The use of pellicles with this purpose represents an economic advantage, avoiding the need for storage in a controlled atmosphere, which would imply in operational costs and equipment usage. The function of the pellicle depends on the food product and mainly on the kind of deterioration which such product is submitted to (Maia; Porte; Souza, 2000). Thus, this work aimed at using kefir as a technique of blueberry - cultivar Florida $\mathrm{M}$ - post-harvest conservation.

\section{MATERIAL AND METHODS}

The fruits proceeding from Caxias do Sul, Rio Grande do Sul, were harvested in a fully maturation stage, when they show a violet coloration and presence of blooming. (Childers; Lyrene, 2006) They were taken to the Laboratory of Food Biochemistry from Universidade
Estadual de Maringá, Paraná. The fruits were selected and cleaned, being afterwards covered in eatable biofilm made of kefir grains. After being dried at room temperature, they were conditioned in plastic trays that were put into the storage areas. It was used a partially randomized design, with three repetitions, in a factorial structure $3 \times 2 \times 6$ (storage temperatures: $2^{\circ} \mathrm{C}, 5{ }^{\circ} \mathrm{C}$ and room temperatures; treatments: control and kefir) and storage periods: $0,3,6$, 9,12 and 15 days). Total phenolic compounds, carotenoids and anthocyanins were evaluated in accordance with Lee's protocol (Lees; Francis, 1972). We also evaluated fresh mass loss $(\%), \mathrm{pH}$, total soluble solids (refractometer) and total titratable acidity, expressed in percentage of citric acid, by the solution neutralization (AOAC, 1992).

The used eatable covering was made with kefir grains and water $400 \mathrm{~g}$ of kefir grains were mixed with $1.5 \mathrm{~L}$ of distilled water and maintained under agitation and heating at $50{ }^{\circ} \mathrm{C}$ for 30 minutes. After this period 10 $\mathrm{mL}$ of glycerol and $10 \mathrm{~g}$ of sorbitol were added and the solution was kept under agitation for 2 minutes. After cooling, the suspension had its volume increased by $2 \mathrm{~L}$ using a graduated flask. The fruits were immersed for 3 minutes in this solution and laid on nylon net, in order to dry at room temperature. After being dried, the fruits were weighed and conditioned in PVC trays.

\section{RESULTS AND DISCUSSION}

In all different storage temperatures (room, $2{ }^{\circ} \mathrm{C}$ and $5{ }^{\circ} \mathrm{C}$ ), the fruits mass loss gradually increased during the 15 day storage, being that it could be observed in the results that the fruits with kefir covering had a lower mass loss.

At $2{ }^{\circ} \mathrm{C}$, during the storage period, the averages of mass loss, when comparing the control treatment (T1) and the treatment with kefir (T2), were similar. On the other hand, at room temperature and at $5{ }^{\circ} \mathrm{C}$, the averages were different between $\mathrm{T} 1$ and $\mathrm{T} 2$, once it was observed that, from the third storage day, the mass loss were lower for treatment $\mathrm{T} 2$, showing that the treatment with kefir can be used as an alternative for conservation and increase blueberry commercialization period (Table1).

At the end of 15 days, the mass losses at room temperature, at $2{ }^{\circ} \mathrm{C}$ and at $5{ }^{\circ} \mathrm{C}$ were, respectively 33.54 , 10.92 and $14.05 \%$ for the control treatment and 13.02 , 9.95 and $5.02 \%$ for the treatment with kefir. Thus, it can be observed that storage at room temperature was inefficient to conserve the fruits. Besides the high mass loss, the fruits stored at room temperature already had some fungi after 6 days of storage only (Table 1 ). 
The results on total soluble solids (TSS) observed at room temperature and at $2{ }^{\circ} \mathrm{C}$ did not show any difference between the treatments during the storage period. At room temperature, TSS content was between 11.53 and $15.7^{\circ}$ Brix for the control treatment and between 10.5 and $11.43{ }^{\circ}$ Brix for the fruits treated with kefir, showing the influence of kefir in fruit conservation. There were differences between the treatments on days 3 and 12 , when stored at $5{ }^{\circ} \mathrm{C}$. The decrease in TSS content that sometimes occurred during storage time can be explained by the fact that sugars and acids are used as substrates in the respiration process (Table 2).

The $\mathrm{pH}$ results for the studied temperatures showed differences among the average values, observed on the third day of storage at room temperature. From the third day to the end of the storage period, $\mathrm{pH}$ variation for fruits treated with kefir was always lower. At $2{ }^{\circ} \mathrm{C}$, the differences were visible on days 12 and 15 . It was observed that there was an increase in $\mathrm{pH}$ during the storage days, being that on time zero, the value was 2.97 for control treatment and 2.96 for fruits with kefir. At the end of the storage period, the values observed were 3.33 and 3.26 , respectively. The average $\mathrm{pH}$ values of blueberries stored at $5{ }^{\circ} \mathrm{C}$ also had some differences on days 12 and 15 (Table3).

The results obtained for acidity, at room temperature, showed a linear growth for both treatments, during the 15 days of storage. This temperature was inefficient for this characteristic, because the excessive increase in blueberry acidity may cause undesirable organoleptic alterations, jeopardizing its commercialization. On time zero, the acidity values were 1.59 and $1.62 \mathrm{~g} .100 \mathrm{~g}^{-1}$ of citric acid for $\mathrm{T} 1$ and $\mathrm{T} 2$, respectively. At the end of the storage period, the values observed were: 6.08 and $5.88 \mathrm{~g} .100 \mathrm{~g}^{-1}$ of citric acid for $\mathrm{T} 1$ and $\mathrm{T} 2$, respectively. The values of titratable acidity observed for $2{ }^{\circ} \mathrm{C}$ and $5{ }^{\circ} \mathrm{C}$ also showed an increase, though non-linear (Table 4).

Table 1 - Averages of values found for mass loss in organic blueberries, cultivar Florida M, covered with kefir grains $(n=3)$.

\begin{tabular}{crrrrrc}
\hline Temperature & \multicolumn{2}{c}{ Room } & \multicolumn{2}{c}{$5^{\circ} \mathrm{C}$} & \multicolumn{2}{c}{$2^{\circ} \mathrm{C}$} \\
\hline Days/Treatment & \multicolumn{1}{c}{$\mathrm{T} 1$} & \multicolumn{1}{c}{$\mathrm{T} 2$} & $\mathrm{~T} 1$ & $\mathrm{~T} 2$ & $\mathrm{~T} 2$ \\
\hline 3 & $5.08 \mathrm{aD}$ & $1.86 \mathrm{bC}$ & $3.62 \mathrm{aE}$ & $1.12 \mathrm{bC}$ & $4.24 \mathrm{aC}$ & $2.19 \mathrm{aB}$ \\
6 & $9.89 \mathrm{aC}$ & $4.15 \mathrm{bC}$ & $5.84 \mathrm{aD}$ & $1.98 \mathrm{bC}$ & $5.59 \mathrm{aC}$ & $4.05 \mathrm{bB}$ \\
9 & $17.23 \mathrm{aB}$ & $7.34 \mathrm{bB}$ & $8.82 \mathrm{aC}$ & $3.65 \mathrm{bB}$ & $8.08 \mathrm{aA}$ & $7.62 \mathrm{aB}$ \\
12 & $24.55 \mathrm{aA}$ & $10.34 \mathrm{bA}$ & $10.94 \mathrm{aB}$ & $4.11 \mathrm{bAB}$ & $9.84 \mathrm{bA}$ & $8.36 \mathrm{bA}$ \\
15 & $33.54 \mathrm{aC}$ & $13.02 \mathrm{bA}$ & $14.05 \mathrm{aA}$ & $5.02 \mathrm{bA}$ & $19.92 \mathrm{aB}$ & $9.96 \mathrm{aA}$ \\
\hline
\end{tabular}

${ }^{1}$ Average values followed by the same capital letter, in each column, do not differ by Tukey's test at $5 \%$ of probability. ${ }^{2}$ Average values followed by the same lowercase letter, in each line, do not differ by Tukey's test at $5 \%$ of probability. $n=$ number of replicates; $\mathrm{T} 1=$ treatment without covering; $\mathrm{T} 2=$ treatment with kefir grains.

Table 2 - Average values for total titratable solids (TSS) in organic blueberries, cultivar Florida M, covered with kefir grains $(\mathrm{n}=3)$.

\begin{tabular}{ccccccc}
\hline Temperature & \multicolumn{2}{c}{ Room } & \multicolumn{2}{c}{$5^{\circ} \mathrm{C}$} & \multicolumn{2}{c}{$2^{\circ} \mathrm{C}$} \\
\hline Days/Treatment & $\mathrm{T} 1$ & $\mathrm{~T} 2$ & $\mathrm{~T} 1$ & $\mathrm{~T} 2$ & $\mathrm{~T} 1$ & $\mathrm{~T} 2$ \\
\hline 0 & $13.97 \mathrm{aB}$ & $14.23 \mathrm{aB}$ & $11.97 \mathrm{aB}$ & $13.37 \mathrm{aA}$ & $12.5 \mathrm{bA}$ & $11.53 \mathrm{bA}$ \\
3 & $14.33 \mathrm{aC}$ & $14.27 \mathrm{aB}$ & $11.83 \mathrm{bB}$ & $11.73 \mathrm{aB}$ & $12.63 \mathrm{bA}$ & $13.63 \mathrm{bB}$ \\
6 & $13.13 \mathrm{aA}$ & $14.43 \mathrm{aB}$ & $12.43 \mathrm{aA}$ & $14.00 \mathrm{aC}$ & $13.67 \mathrm{aA}$ & $13.43 \mathrm{aC}$ \\
9 & $11.37 \mathrm{bB}$ & $13.47 \mathrm{bB}$ & $11.80 \mathrm{bB}$ & $14.1 \mathrm{bB}$ & $12.23 \mathrm{aB}$ & $13.57 \mathrm{aC}$ \\
12 & $11.53 \mathrm{aA}$ & $14.10 \mathrm{aA}$ & $10.80 \mathrm{aA}$ & $13.43 \mathrm{bB}$ & $14.43 \mathrm{aB}$ & $14.30 \mathrm{aC}$ \\
15 & $15.70 \mathrm{aC}$ & $13.87 \mathrm{aB}$ & $10.50 \mathrm{bB}$ & $13.67 \mathrm{bC}$ & $14.17 \mathrm{aA}$ & $14.50 \mathrm{aA}$ \\
\hline
\end{tabular}

${ }^{1}$ Average values followed by the same capital letter, in each column, do not differ by Tukey's test at $5 \%$ of probability. ${ }^{2}$ Average values followed by the same lowercase letter, in each line, do not differ by Tukey's test at $5 \%$ of probability. $n=$ number of replicates; $\mathrm{T} 1=$ treatment without covering; $\mathrm{T} 2$ = treatment with kefir grains. 
Table 3 - Average of $\mathrm{pH}$ values determined in organic blueberries, cultivar Florida M, covered with kefir grains $(\mathrm{n}=3)$.

\begin{tabular}{ccccccc}
\hline Temperature & \multicolumn{2}{c}{ Room } & \multicolumn{2}{c}{$5^{\circ} \mathrm{C}$} & \multicolumn{2}{c}{$2^{\circ} \mathrm{C}$} \\
\hline Days/Treatment & $\mathrm{T} 1$ & $\mathrm{~T} 2$ & $\mathrm{~T} 1$ & $\mathrm{~T} 2$ & $\mathrm{~T} 1$ & $\mathrm{~T} 2$ \\
\hline 0 & $2.95 \mathrm{aB}$ & $2.99 \mathrm{aB}$ & $2.96 \mathrm{aB}$ & $2.96 \mathrm{aA}$ & $2.99 \mathrm{aB}$ & $2.96 \mathrm{aAB}$ \\
3 & $2.92 \mathrm{aB}$ & $2.94 \mathrm{bC}$ & $2.87 \mathrm{aB}$ & $2.92 \mathrm{aA}$ & $2.99 \mathrm{aB}$ & $2.94 \mathrm{aA}$ \\
6 & $3.05 \mathrm{aA}$ & $3.11 \mathrm{bA}$ & $2.95 \mathrm{aB}$ & $3.13 \mathrm{aC}$ & $2.77 \mathrm{aBC}$ & $2.85 \mathrm{aA}$ \\
9 & $2.74 \mathrm{aC}$ & $2.95 \mathrm{bB}$ & $2.56 \mathrm{aA}$ & $2.95 \mathrm{aB}$ & $2.97 \mathrm{bB}$ & $2.93 \mathrm{bA}$ \\
12 & $2.88 \mathrm{bC}$ & $3.13 \mathrm{aA}$ & $2.88 \mathrm{aB}$ & $3.18 \mathrm{bB}$ & $2.21 \mathrm{aA}$ & $3.15 \mathrm{bA}$ \\
15 & $2.98 \mathrm{aB}$ & $3.30 \mathrm{bC}$ & $2.93 \mathrm{aB}$ & $3.25 \mathrm{bC}$ & $3.33 \mathrm{aC}$ & $3.26 \mathrm{bB}$ \\
\hline
\end{tabular}

${ }^{1}$ Average values followed by the same capital letter, in each column, do not differ by Tukey's test at $5 \%$ of probability. ${ }^{2}$ Average values followed by the same lowercase letter, in each line, do not differ by Tukey's test at $5 \%$ of probability. $n=$ number of replicates; $\mathrm{T} 1=$ treatment without covering; $\mathrm{T} 2=$ treatment with kefir grains.

Table 4 -Average values for acidity determined in organic blueberries, cultivar Florida $\mathrm{M}$, covered with kefir grains $(\mathrm{n}=3)$.

\begin{tabular}{|c|c|c|c|c|c|c|}
\hline \multirow{2}{*}{$\frac{\text { Temperature }}{\text { Days/Treatment }}$} & \multicolumn{2}{|c|}{ Room } & \multicolumn{2}{|c|}{$5^{\circ} \mathrm{C}$} & \multicolumn{2}{|c|}{$2^{\circ} \mathrm{C}$} \\
\hline & $\mathrm{T} 1$ & $\mathrm{~T} 2$ & $\mathrm{~T} 1$ & $\mathrm{~T} 2$ & $\mathrm{~T} 1$ & $\mathrm{~T} 2$ \\
\hline 0 & $1.59 \mathrm{aE}$ & $1.62 \mathrm{aD}$ & $1.61 \mathrm{aBC}$ & $1.58 \mathrm{aD}$ & $1.63 \mathrm{aB}$ & $1.58 \mathrm{aB}$ \\
\hline 3 & $1.68 \mathrm{bE}$ & $2.02 \mathrm{aD}$ & $1.54 \mathrm{aC}$ & $1.63 \mathrm{aD}$ & $1.43 \mathrm{aB}$ & $1.56 \mathrm{bB}$ \\
\hline 6 & $2.16 \mathrm{bD}$ & $2.69 \mathrm{aC}$ & $1.73 \mathrm{aB}$ & $1.66 \mathrm{aCD}$ & $1.94 \mathrm{aA}$ & $2.11 \mathrm{bC}$ \\
\hline 9 & $3.24 \mathrm{bC}$ & $4.46 \mathrm{aB}$ & $1.76 \mathrm{aB}$ & $1.85 \mathrm{aC}$ & $1.96 \mathrm{aA}$ & $2.08 \mathrm{bBC}$ \\
\hline 12 & $5.53 \mathrm{aB}$ & $5.72 \mathrm{aA}$ & $2.17 \mathrm{bA}$ & $2.36 \mathrm{aA}$ & $2.21 \mathrm{aA}$ & $2.82 \mathrm{aA}$ \\
\hline 15 & $6.08 \mathrm{aA}$ & $5.88 \mathrm{aA}$ & $2.03 \mathrm{bA}$ & $1.17 \mathrm{aB}$ & $1.95 \mathrm{aA}$ & $2.13 \mathrm{aC}$ \\
\hline
\end{tabular}

${ }^{1}$ Average values followed by the same capital letter, in each column, do not differ by Tukey's test at $5 \%$ of probability. ${ }^{2}$ Average values followed by the same lowercase letter, in each line, do not differ by Tukey's test at $5 \%$ of probability. $n=$ number of replicates; $\mathrm{T} 1=$ treatment without covering; $\mathrm{T} 2=$ treatment with kefir grains.

Total carotenoid content in blueberry stored at room temperature varied from $2.00 \mathrm{mg} . \mathrm{mL}^{-1}$ on time zero, to $3.31 \mathrm{mg} \cdot \mathrm{mL}^{-1}$ at the end of the storage time, for the control treatment. The highest value obtained was $3.42 \mathrm{mg} \cdot \mathrm{mL}^{-1}$ on day 12 . For the treatment with kefir, the results found varied between 2.99 and $5.21 \mathrm{mg} \cdot \mathrm{mL}^{-1}$. At $2{ }^{\circ} \mathrm{C}$, total carotenoid contents did not show significant differences, at the level of $5 \%$, between the treatments. The highest total carotenoid contents observed, on both treatments (T1 and T2) were found on time zero, corresponding to 4.07 and $4.59 \mathrm{mg} \cdot \mathrm{mL}^{-1}$, respectively (Table 5).

For storage at $5{ }^{\circ} \mathrm{C}$, there were significant differences on total carotenoid content, at the level of $5 \%$, on days 6,9 and 12 , being that on day 6 , the highest total carotenoid content was observed on the control treatment (4.65 mg. $\mathrm{mL}^{-1}$ ), and on treatment $\mathrm{T} 2$, the highest content observed was $4.71 \mathrm{mg} \cdot \mathrm{mL}^{-1}$, on time zero (Table 5).
Regarding values of anthocyanins, a variation was observed throughout the 15 days of storage, which can be explained by some kind of degradation during the blueberry period of maturation. A great content of anthocyanins was observed in these fruits, though they were very instable. In all storage temperatures, anthocyanin content showed no statistical difference between the treatments, at the level of $5 \%$ of significance. At room temperature, the anthocyanin content for $\mathrm{T} 1$ and $\mathrm{T} 2$ were lower than on the harvest day (Table 6).

The presence of a large amount of these compounds in blueberry fruits proves their benefits and importance for health. Therefore, due to their short post-harvest life, studies aiming at conserving them are important for both improving the commercialization of fresh fruits and for using them in processing industries. 
Table 5 - Average values for total carotenoid content in organic blueberries, cultivar Florida M, covered with kefir grains $(n=3)$.

\begin{tabular}{cllllll}
\hline Temperature & \multicolumn{2}{c}{ Room } & \multicolumn{2}{c}{$5^{\circ} \mathrm{C}$} & \multicolumn{3}{c}{$2^{\circ} \mathrm{C}$} \\
\hline Days/Treatment & $\mathrm{T} 1$ & $\mathrm{~T} 2$ & $\mathrm{~T} 1$ & $\mathrm{~T} 2$ & $\mathrm{~T} 1$ & $\mathrm{~T} 2$ \\
\hline 0 & $2.01 \mathrm{aAB}$ & $4.17 \mathrm{bB}$ & $5.21 \mathrm{bA}$ & $4.71 \mathrm{bA}$ & $4.07 \mathrm{aB}$ & $4.61 \mathrm{aBC}$ \\
3 & $3.21 \mathrm{aB}$ & $2.91 \mathrm{aAB}$ & $3.15 \mathrm{aB}$ & $2.68 \mathrm{aBC}$ & $3.15 \mathrm{aA}$ & $3.26 \mathrm{aB}$ \\
6 & $3.11 \mathrm{aA}$ & $5.09 \mathrm{bC}$ & $3.97 \mathrm{aA}$ & $3.17 \mathrm{bB}$ & $2.93 \mathrm{bA}$ & $2.62 \mathrm{bC}$ \\
9 & $3.27 \mathrm{bB}$ & $4.65 \mathrm{aC}$ & $3.26 \mathrm{bA}$ & $2.97 \mathrm{aC}$ & $2.71 \mathrm{aA}$ & $3.96 \mathrm{aBC}$ \\
12 & $3.42 \mathrm{bC}$ & $2.98 \mathrm{aA}$ & $2.99 \mathrm{bB}$ & $4.05 \mathrm{aA}$ & $2.82 \mathrm{bA}$ & $2.66 \mathrm{bA}$ \\
15 & $3.31 \mathrm{aB}$ & $3.51 \mathrm{aB}$ & $3.19 \mathrm{aB}$ & $3.43 \mathrm{aB}$ & $4.01 \mathrm{aA}$ & $3.54 \mathrm{aB}$ \\
\hline
\end{tabular}

${ }^{1}$ Average values followed by the same capital letter, in each column, do not differ by Tukey's test at $5 \%$ of probability. ${ }^{2}$ Average values followed by the same lowercase letter, in each line, do not differ by Tukey's test at $5 \%$ of probability. $n=$ number of replicates; $\mathrm{T} 1=$ treatment without covering; $\mathrm{T} 2=$ treatment with kefir grains.

Table 6 - Average values for anthocyanins in organic blueberries, cultivar Florida M, covered with kefir grains $(n=3)$.

\begin{tabular}{ccccrrc}
\hline Temperature & \multicolumn{2}{c}{ Room } & \multicolumn{2}{c}{$5^{\circ} \mathrm{C}$} & \multicolumn{2}{c}{$2^{\circ} \mathrm{C}$} \\
\hline Days/Treatment & $\mathrm{T} 1$ & $\mathrm{~T} 2$ & $\mathrm{~T} 1$ & $\mathrm{~T} 2$ & $\mathrm{~T} 2$ \\
\hline 0 & $57.53 \mathrm{aBC}$ & $75.41 \mathrm{aB}$ & $63.09 \mathrm{aC}$ & $68.60 \mathrm{aB}$ & $65.31 \mathrm{aC}$ & $63.13 \mathrm{aA}$ \\
3 & $176.16 \mathrm{aA}$ & $181.35 \mathrm{aB}$ & $153.81 \mathrm{bA}$ & $204.33 \mathrm{aA}$ & $187.19 \mathrm{aA}$ & $175.99 \mathrm{aA}$ \\
6 & $59.17 \mathrm{aB}$ & $49.95 \mathrm{aB}$ & $60.74 \mathrm{aC}$ & $65.09 \mathrm{aB}$ & $62.75 \mathrm{bC}$ & $53.73 \mathrm{bA}$ \\
9 & $35.17 \mathrm{aBC}$ & $62.04 \mathrm{aAB}$ & $107.56 \mathrm{aBC}$ & $83.11 \mathrm{aB}$ & $87.15 \mathrm{aB}$ & $79.89 \mathrm{aB}$ \\
12 & $27.25 \mathrm{aC}$ & $45.79 \mathrm{aB}$ & $93.31 \mathrm{aB}$ & $72.28 \mathrm{aB}$ & $69.36 \mathrm{aC}$ & $68.53 \mathrm{aAB}$ \\
15 & $28.02 \mathrm{bC}$ & $36.64 \mathrm{aB}$ & $73.66 \mathrm{aBC}$ & $81.05 \mathrm{aB}$ & $86.82 \mathrm{aBC}$ & $82.89 \mathrm{aB}$ \\
\hline
\end{tabular}

${ }^{1}$ Average values followed by the same capital letter, in each column, do not differ by Tukey's test at $5 \%$ of probability. ${ }^{2}$ Average values followed by the same lowercase letter, in each line, do not differ by Tukey's test at $5 \%$ of probability. $n=$ number of replicates; $\mathrm{T} 1=$ treatment without covering; $\mathrm{T} 2=$ treatment with kefir grains.

\section{CONCLUSION}

The use of covering made of kefir grains, associated with a temperature of $5{ }^{\circ} \mathrm{C}$, has been proven as an efficient alternative in conservation and increase in the shelf-life of organic blueberry, not changing the chemical composition and nutritional of blueberry.

\section{REFERENCES}

ANTUNES, L.E.C.; MADAIL, J.C.M. Mirtilo: que negócio é este?. Jornal da Fruta, Lages. 13:8, 2005

ANTUNES, L.E.C.; RASEIRA, M.C.B. (Ed.). Cultivo do mirtilo (Vaccinium spp.). Pelotas: Embrapa Clima Temperado, 2006. 99p. (Embrapa Clima Temperado. Sistema de Produção, 8).
ASSOCIATION OF OFFICIAL AGRICULTURAL CHEMISTS. Official methods of analysis of the Association of the Agricultural Chemists. 12 ed. Washington: A.O.A.C., 1992.

AZEREDO, H. M. C. de. Películas comestíveis em frutas conservadas por métodos combinados: potencial da aplicação. Boletim do CEPPA. 21(2), 2003.

BRAZELTON, D.; STRIK, B.C. Perspective on the U.S. and global blueberry industry. Journal of the American Pomological Society. 61:144-147, 2007.

CHILDERS, N.F.; LYRENE, P.M. Blueberries for growers, gardeners, promoters. Florida: E. O. Painter Printing Company, 2006. 266p. 
DONADIO, L.C.; NACHTIGAL, J.C.; SACRAMENTO, C.K. Frutas exóticas. FCAV-

UNESP. Jaboticabal, SP. 1998. 279p.

EHLENFELDT, M.K. et al. Floral bud cold hardiness of Vaccinium ashei, V. constablaei, and hybrid derivatives and the potencial for producing Northern-adapted rabbiteye cultivars. HortScience. 42:1131-1134, 2007.

GIADA, M. L. R.; MANCINI FILHO, J. Importância dos compostos fenólicos da dieta na promoção da saúde humana. Publicativo UEPG Ciências Biológicas e da Saúde. 12(4):7-15, 2006.

JARA AYALA, F. DE LA. Amora - Frambuesa Grosella - Kivi - Mirtilo e sua comercialização. Cinco Continentes Editora Ltda. Porto Alegre, RS. 1999. $57 \mathrm{p}$.

MAIA, L. H.; PORTE, A.; SOUZA, V. F. de. Filmes comestíveis: aspectos gerais, propriedades de barreira à umidade e o oxigênio. Boletim do CEPPA. 18(1), 2000.

LEES, D. H.; FRANCIS, F. J. Standardization of pigment analyses in cranberries. HortScience. 7(1):8384, 1972.
MANACH, C. et al. Polyphenols: food sources and bioavailability. American Journal of Clinical Nutrition. 79(5):727-747, 2004.

PRIOR, R. L. et al. Antioxidant capacity as influenced by total phenolic and anthocyanin content, maturity and variety of Vaccinium species. Journal of Agriculture and Food Chemistry. 46:2686-2693, 1998.

STAHL, W., SIES, H. Antioxidant activity of carotenoids. Molecular Aspects of Medicine. 24:345-351, 2003.

STRIK, B. Blueberry: an expanding world crop.

Chronica Horticulturae. 45:7-12, 2005.

STRIK, B.C. Horticultural practices of growing highbush blueberries in the ever-expanding U.S. and global scene. Journal of the American Pomological Society. 61:148-150, 2007.

WANG, H., CAO, G.; PRIOR, R. L. 1997. Oxygen radical absorbing capacity of anthocyanins. Journal of Agricultural and Food Chemistry. 45:304-309, 1997.

WOLFE, K.; WU, X.; LIU, R. H. Antioxidant activity of apple peels. Journal of Agricultural and Food Chemistry. 53:609-614, 2003. 